\title{
Kepemimpinan Perempuan di Pemerintah Daerah: Kajian Kepemimpinan Perempuan Walikota Tangerang Selatan
}

\author{
Luki Oka Prastio ${ }^{1}$, Abdillah $^{2}$, Elly Nurlia ${ }^{3}$, Tati ${ }^{3}$ \\ 1,3Univesitas Mathla'ul Anwar Banten, Jl Raya Labuan KM 23 Saketi Kab. Pandeglang - Banten \\ 2Media Ilmiah Center, Jl. Muhajirin Makassar \\ 4Universitas Muhammadiyah Bandung, Jl. Soekarno - Hatta No. 752, Bandung \\ Corresponding Author: luky18003@mail.unpad.ac.id
}

\section{Keyword:}

Women's Leadership;

Local Goverment;

Social Justice

Kata Kunci:

Kepemimpinan

Perempuan;

Pemerintah Daerah;

Keadilan Sosial

\begin{abstract}
This research is based on the background of women's leadership which is considered capable of bringing improvements to things that rarely get attention. One of them is the lack of attention, the vulnerability of protection, and the lack of policies that favor women and children. Referring to the research focus that the Mayor of South Tangerang is trying to improve the conditions of degradation of women and children who often receive less attention. This study uses a qualitativeexploratory method with a narrative approach that relates to women's leadership in South Tangerang City. Data analysis using Nvivo 12 Pro tools to help researchers explore more deeply related to the problem. The results of this study indicate that the Mayor of South Tangerang is a leader who directs his staff in meeting the needs of women and children. In addition to having a close relationship with the community, the Mayor of South Tangerang facilitated by forming a task force for the protection of women and children as a form of support in accommodating and minimizing the problems that often occur to women and children in the City of South Tangerang.
\end{abstract}

\begin{abstract}
Abstrak: Penelitian ini di latar belakangi kepemimpinan perempuan yang dianggap mampu membawa perbaikan terhadap hal-hal yang jarang mendapat perhatian. Salah satunya yaitu lemahnya perhatian, rentannya perlindungan, dan masih minimnya kebijakan yang berpihak terhadap perempuan dan anak-anak. Merujuk pada fokus penelitian bahwa Walikota Tangerang Selatan berusaha memperbaiki kondisi degradasi terhadap perempuan dan anak-anak yang kerap kurang mendapat perhatian. Penelitian ini menggunakan metode kualitatifeksploratif dengan pendekatan Naratif yang berhubungan dengan kepemimpinan perempuan di Kota Tangerang Selatan. Analisis data menggunakan tools Nvivo 12 Pro untuk membantu peneliti mengeksporasi permasalahan. Hasil penelitian ini menunjukan Walikota Tangerang Selatan merupakan pemimpin yang mengarahkan jajarannya dalam memenuhi kebutuhan perempuan dan anak-anak. Di samping memiliki kedekatan dengan masyarakat Walikota Tangerang Selatan menfasilitasi dengan membentuk satgas perlindungan perempuan dan anak sebagai bentuk dukungan dalam mangakomodir dan meminimalisir permasalahan yang kerap terjadi pada perempuan dan anak di Kota Tangerang Selatan.
\end{abstract}

Informasi Artikel: Disubmit: 06-08-2021, Revisi: 28-08-2021, Diterima: 30-09-2021

\section{PENDAHULUAN}

Partisipasi perempuan dalam menduduki posisi penting kepemimpinan publik, baik dalam partai politik maupun birokrasi pemerintahan, menjadi fenomena menarik sejak akhir abad ke-20 (Kaloh, 2009; Fakih, 1996; Suradinata, 2007; Parker, 1996; Malik, et al, 2021; 
Pasolong, 2013). Di Indonesia, keterlibatan perempuan dalam politik sudah dimulai sejak lama (Abdillah et al., 2020: 67-81; Malik et al., 2021). Keterlibatan perempuan dalam kepemimpinan publik di tanah air sendiri mencapai puncaknya saat tampuk kepresidenan diduduki Megawati Soekarno Putri sebagai Presiden Republik Indonesia ke-5. Di samping itu sejumlah perempuan juga tampil sebagai menteri kabinetnya. Bisa dikatakan, era kepresidenan Megawati menjadi tonggak penting keterlibatan perempuan dalam pemerintahan.

Seiring dewasanya proses demokrasi mendorong sejumlah perempuan dalam beberapa dekade terakhir ikut berpartisipasi dalam proses politik, seperti menjadi kontestan pemilihan jabatan eksekutif seperti pemilihan presiden (pilpres), pemilihan gubernur (pilgub), pemilihan kepala daerah (pilkada) (Luhur \& Abdillah, 2020). Terbukti bahkan tidak sedikit diantara mereka yang berhasil meraih suara pemilih yang mengantar mereka ke kursi kepemimpinan. Berdasarkan data Kementerian Pemberdayaan Perempuan dan Perlindungan Anak (KPPPA) mencatat, hingga akhir tahun 2016 jumah kepala daerah perempuan di seluruh Indonesia mencapai 37 orang. Dalam catatan Perludem 2017, jumlah perempuan yang berhasil pemimpin di wilayah publik dengan menjadi kepala daerah kembali meningkat di tahun berikutnya dengan bertambahnya perempuan kepala daerah baru sebanyak 10 orang sehingga total perempuan yang menjadi kepala daerah mencapai 47 orang.

Terlepas dari presentase keterwakilannya, keterlibatan perempuan dalam tampuk kepemimpinan di wilayah publik menjadi keistimewaan sendiri, terutama jika dibandingkan dengan beban tanggung jawab yang harus mereka penuhi sebagai seorang pemimpin (Kaloh, 2009; Suradinata, 2007; Malik, et al, 2021; Pasolong, 2013). Diketahui bahwa kepemimpinan (leadership) merupakan peran publik yang tidak mengistimewakan atau mengecualikan kelompok tertentu, termasuk perempuan (Applebaun, Audet, Miller, 2002). Dalam hal ini, para perempuan pemimpin publik akan diuji dalam melakukan tata kelola, menangkap arus keinginan publik, dan kemampuan mengambil keputusan. Selaras dengan hal tersebut Kanter (1977) menegaskan bahwa kepemimpinan lebih banyak memandang pada horizon yang luas (keeping eye on the horizon) dan menekankan hasil-hasil jangka panjang (long term result).

Di daerah, terutama Provinsi Banten, tingginya keterlibatan perempuan dalam kepemimpinan sangat menarik untuk ditelisik. Salah satunya merujuk pada kepemimpinan Airin Rachmy Diani sebagai Walikota Tangerang Selatan yang mana dalam era kepemimpinannya memiliki fokus terhadap perempuan dan anak yang tidak jarang luput dari perhatian kepala derah lainnya. Lemahnya perhatian terhadap perempuan dan anak khususnya di Provinsi Banten termanifestasi dari tingginya kasus Kekerasan Dalam Rumah Tangga (KDRT). Berdasarkan data Pusat Pelayanan Terpadu Pemberdayaan Perempuan dan Anak (P2TP2A) tercatat sejak Tahun 2010 hingga September 2017, terdapat sebanyak 442 kasus kekerasan terhadap perempuan dan anak. Akumulasi jumlah tersebut terdiri dari KDRT sebanyak 154 kasus, kekerasan/penelantaran anak sebanyak 96 kasus, dan kekerasan seksual sebanyak 100 kasus (Ridho, 2017; Riskasari, R., 2021; Yusuf, M., et al., 2020).

Pada gambar 1 di bawah menjelaskan identifikasi dan analisis issu penelitian tentang kepemimpinan perempuan, menghadapai kondisi pemenuhan kebutuhan perempuan dan anak di pemerintahan daerah di Kota Tangerang Selatan masa 2011-2021. Kondisi terhadap pemenuhan kebutuhan perempuan dan anak merupakan tanggungjawab kepala daerah sebagai pemegang otoritas tertinggi. Salah satu yang menjadi perhatian kepala daerah (Prianto et al., 2021) khususnya di Provinsi Banten yaitu masih tingginya kasus penderita gizi buruk. Kalkulasi pederita gizi buruk di Provinsi Banten pada awal tahun 2019 sebanyak 2.934 anak (Eko, 2019; Prastio et al., 2019: 200-223). Di Tangerang Selatan terkonfoirmasi sejak Januari 2018 terdapat 59 anak menderita gizi buruk. 


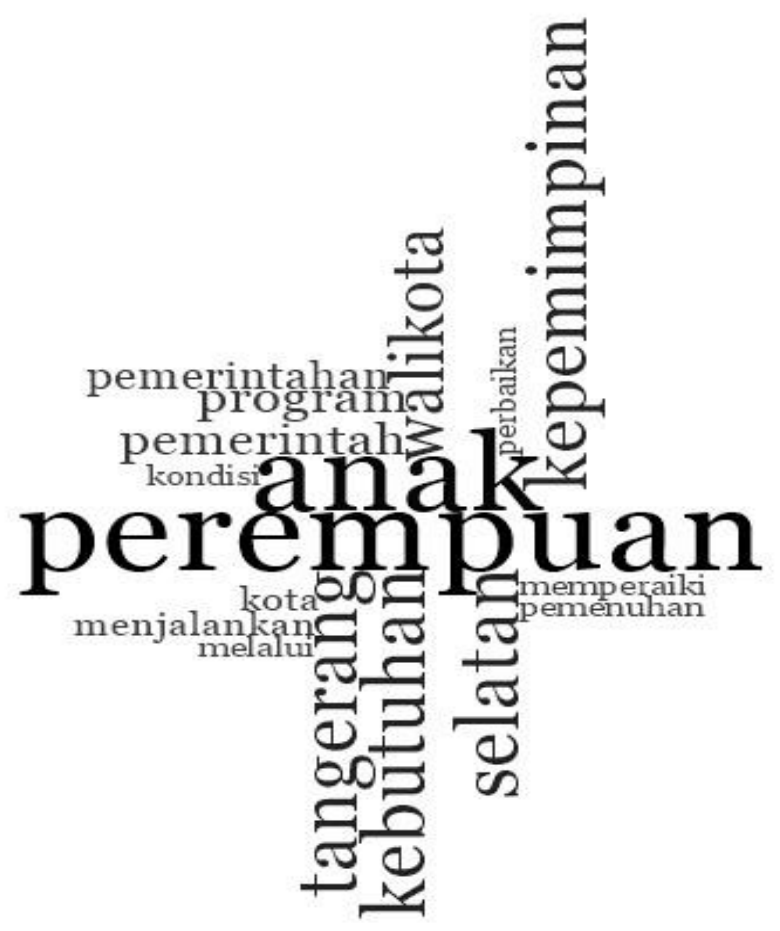

Gambar 1. Identifikasi dan Analisis Masalah Penelitian Sumber: Olahan Peneliti dengan Nvivo 12 Pro, 2021

Kondisi tersebut diperparah dengan Kasus Tindak Pidana Perdagangan Orang (TPPO) hingga kekerasan seksual terhadap anak dan perempuan di Banten terbilang tinggi. Berdasarkan data Sistem Informasi Online Perlindungan Perempuan dan Anak (Simfoni PPA) Kementerian Pemberdayaan Pemberdayaan Perempuan dan Perlindungan Anak (KPPA) RI, TPPO di Provinsi Banten pada tahun 2014 tercatat 21 orang, 19 orang pada 2015, serta 6 orang pada 2017 (Sahurina, 2020; Adiguna, A. P. et al., 2020).

Hal di atas menegaskan masih rentannya perlindungan (Tati et al., 2021; Prastio, L. O., 2019: 62-73) terhadap perempuan dan anak saat ini. Dinas Pemberdayaan Masyarakat, Perlindungan Perempuan, Perlindungan Anak, dan Keluarga Berancana (DPMP3AKB) Tangerang Selatan mengungkapkan kasus kekerasan anak di Kota Tangerang Selatan masih tinggi. Berasarkan data DPMP3AKB pada tahun 2018, dari 165 kasus kekerasan sekitar 120 kasus korbannya adalah anak-anak. Salah satu yang menjadi pemicu hal tersebut terjadi karena anak berada pada posisi lemah, dan kurangnya perhatian lingkungan sekitar terhadap kekrasan yang terjadi pada anak, di samping perlunya respon tanggap kepala daerah dalam memperbaiki kondisi tersebut (Guritno, 2019; Anirwan \& Annas, 2020).

Berdasarkan uraian di atas timbul sebuah pertanyaan, bagaimanakah sifat kepemimpinan perempuan dalam menjalankan roda pemerintahan, terutama dalam memperaiki kondisi pemenuhan kebutuhan perempuan dan anak di Kota Tangerang Selatan.

\section{METODE PENELITIAN}

Bagian ini berisi rancangan penelitian, topik/objek/sampel penelitian, definisi Penelitian ini menggunakan metode eksplorasi kualitatif dan metode naratif untuk mengkaji kepemimpinan perempuan dalam Creswell (2015: 63-64). Ditegaskan bahwa "metode kualitatif dipilih karena penelitian ini lebih menekankan pada proses daripada hasil". Selain itu, Moleong (2007:11) mengemukakan bahwa penelitian kualitatif lebih menekankan data berupa teks dan gambar, daripada angka-angka yang dihasilkan dengan menerapkan metode kualitatif. Selain itu, semua yang dikumpulkan berkemungkinan menjadi kunci terhadap apa yang sudah diteliti. Data primer dalam penelitian ini diperoleh dengan cara observasi dan wawancara secara mendalam 
(in-depth interview), Pemilihan informasi dilakukan secara purposive, dimana peneliti ini menentukan kriteria informan yang dianggap banyak memiliki informasi terkait konteks penelitian. Analisis data menggunakan tools penelitian kualitatif Nvivo 12 Pro (Woolf \& Silver, 2017) dalam mengeksplorasi masalah penelitian tentang kepemimpinan perempuan di Kota Tanggerang.

\section{HASIL DAN DISKUSI}

\section{Kepemimpinan yang mengarahkan (Directive Leader) Sebagai Landasan Sinergi}

Realitas penyelenggaraan pemerintahan oleh Waikota Kota Tangerang Selatan Airin Rachmy Diani dianggap banyak membawa perubahan dan memilki karakteristik sebagai pembeda dengan kepala daerah laki-laki. Bertalian dengan ihwal tersebut, dalam penyelenggaraan pemerintahan Airin Rachmy Diani dapat mengarahkan jajarannya dengan baik selaras dengan visi dan misi pemerintah Kota Tangerang Selatan dalam memenuhi kebutuhan perempuan dan anak. Kondisi tersebut termanifstasi dengan berbagai upaya mengarahkan Satuan Kerja Perangkat Daerah (SKPD) guna mencapai hasil kerja yang maksimal. Artikulasi sebagai bukti nyata terkait hal tersebut yaitu dengan dinobatkannya Kota Tangerang Selatan Sebagai Kota Layak Anak (KLA). Berbicara mengenai hal tersebut, menurut Peraturan Daerah Kota Tangerang Selatan Nomor 1 (Perda) tentang Penyelenggaraan Kota Layak Anak Tahun 2018, memiliki pengertian perencanaan kota yang komprehensif dengan sistem pembangunan berbasis hak anak melalui pembangunan terpadu. Sumber daya dan sumber daya pemerintah, masyarakat, dan dunia usaha, serta keberlanjutan kebijakan dan kegiatan, untuk menjamin terwujudnya hak-hak anak.

Kegiatan dalam rangka memberikan arahan terkait tugas pokok yang bermuara pada tujuan SKPD secara langsung maupun tidak sangat membantu secara moral sekaligus sebagai upaya kontrol langsung kepala daerah terhadap jajarannya. Dalam hal ini Walikota Tangerang Selatan melakukan pengarahan terhadap Dinas Pemberdayaan Masyarakat Pemberdayaan Perempuan Perlindungan Anak dan Keluarga Berencana (DPMP3AKB) Kota Tangerang Selatan. Arahan dilakukan dengan kegiatan kunjungan langsung, inspeksi langsung bertujuan memastikan capaian saat ini dan target organisasi di masa yang akan datang. Di samping adanya kontrol melalui forum formal seperti Forum Komunikasi Pimpinan Daerah (FORKOPIMDA), Walikota Tangerang Selatan telah melakukan arahan secara langsung melalui forum SKPD DPMP3KB yang merupakan tidak lanjut dari hasil musyawarah kelurahan dan kecamatan. Selaras dengan hal tersebut Walikota Tangerang Selatan dalam rangka pencapaian serta memberikan bimbingan/arahan secara spesifik terkait bagaimana cara-cara menyelesaikan tugas dalam konteks dalam memenuhi kebutuhan perempuan dan anak pada dinas DPMP3KB. Kondisi tersebut sesuai dengan salah satu aspek kepemimpinan yang baik bahwasanya kepemimpinan yang baik adalah dengan memberikan tekanan/fokus pada masa depan, menekankan fokus pada penentuan arah, di samping menanyakan apa yang akan terjadi.

Hal di atas mengartikulasikan pemenuhan kebutuhan perempuan dan anak sebagai program prioritas. Berdasarkan data Dinas Kesehatan Kota Tangerang Selatan terdapat tren positif angka penurunan gizi buruk angka kematian ibu dan anak. Adanya persentase pengurangan sebesar 60\% terhadap angka kematian ibu. Hal tersebut dilakukan selama tiga (3) tahun terakhir mulai dari tahun 2017, 2018, dan 2019, Dengan catatan bahwa sisa dari $60 \%$ tersebut atau $40 \%$ yaitu terdapat penyakit penyerta atau penyakit bawaan terhadap ibu atau anak. Terkait dengan realitas penderita gizi buruk di Kota Tangerang Selatan pada tahun 2017 sebanyak 109 kasus gizi buruk. Keseriusan pemerintah daerah dalam menangani permasalahan perempuan dan anak terbukti dengan kecepatan dalam tanggapan terhadap penanganan kasus gizi buruk. Dimana pada awal tahun 2018 terkonfirmasi pengurangan dari 109 kasus menjadi 37 kasus gizi buruk (Dinas Kesehatan Kota Tangerang Selatan, 2019). Dominan kasus penderita gizi buruk yang terjadi di wilayah Tangerang Selatan dialami oleh masyarakat yang bukan merupakan penduduk Kota Tangerang Selatan. Hal tersebut terlihat dari Kartu Tanda Penduduk (KTP) atau Kartu Keluarga (KK) yang bukan merupakan warga masyarakat Kota Tangerang 
Selatan, salah satunya berasal dari Bogor maupun daerah lain yang mengadu nasib di wilayah Tangerang Selatan. Namun sebagai komitmen pemerintah dalam mengurangi gizi hal tersebut tetap ditangani oleh pemerintah Kota Tangerang Selatan tanpa adanya diskriminasi.

Sebagai sebuah komitmen guna memenuhi kebutuhan perempuan dan anak, Walikota Tangerang Selatan memiliki antusias tinggi untuk memastikan langsung kondisi masyarakat. Hal tersebut terkonfirmasi dengan semangat mengarahkan jajarannya untuk bersiap diri melakukan kunjungan langsung ke lapangan. Secara aktual dengan mengetahui permasalahan secara rill di lapangan sekaligus menerima masukan dari masyarakat akan dapat melahirkan sebuah tindakan terhadap pemecahan masalah yang tepat sasaran. Kondisi ini sesuai dengan pandangan Hersey Blancad (1982) bahwa inti dari perilaku membimbing adalah sejauh mana pemimpin berpartisipasi dalam komunikasi satu arah. Bentuk bimbingan dalam komunikasi satu arah ini meliputi penentuan peran yang harus dimainkan pengikut, memberi tahu pengikut apa yang harus dilakukan, di mana, dan bagaimana melakukannya, dan memantau pengikut dengan cermat.

Hubungan interpersonal yang baik antara pimpinan dan jajaran atau bawahan menjadi salah satu aspek penentu keberhasilan peyelenggaraan pemerintah daerah. Dalam hal ini Walikota Tangerang Selatan memiliki kedekatan dengan SKPD serta dapat dikatakan bersahabat dengan masyarakat, di samping mampu memberikan terobosan pelayanan terhadap masyarakat yang fokus terhadap permasalahan pendidikan, masalah perempuan dan anak. Mengarah kepada salah satu implementor dalam penyelenggaraan kegiatan/program yang memenuhi kebutuhan perempuan dan anak Walikota Tangerang Selatan memiliki kepedulian yang tinggi kepada perempuan dan anak-anak. Artikulasi komitmen dalam memenuhi kebutuhan perempuan dan anak salah satunya dimulai dari pemenuhan fasilitas yang ramah anak.

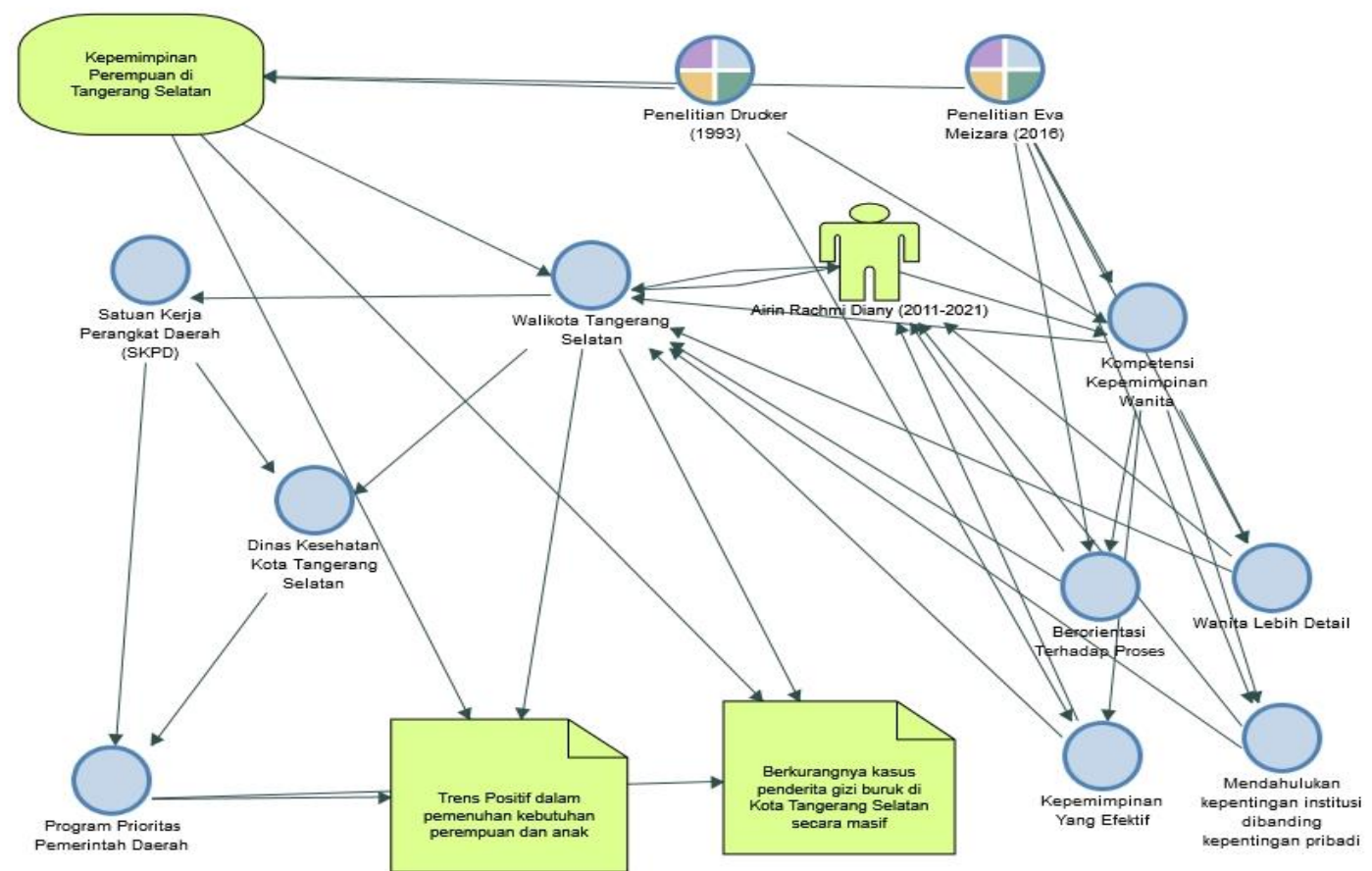

Gambar 2. Orientasi Kepemimpian Walikota Tangerang Selatan Periode 2011-2021 Sumber: Olahan Peneliti dengan Nvivo 12 Pro, 2021

Ketelitian Walikota Tangerang Selatan dalam mengarahkan dan memenuhi kebutuhan organisasi merupakan salah satu pembeda. Ihwal di atas selaras dengan hasil penelitian Eva Meizara (2016) berjudul "Analisis Kompetensi Kepemimpinan Wanita" yang menyatakan kepemimpinan wanita lebih detail, berorientasi terhadap proses. Mendahulukan kepentingan institusi dibanding kepentingan pribadi. Senada dengan itu, Kaloh (2009) \& Pasolong (2013) menjelaskan pemimpin merupakan sumber daya pokok yang paling langka dalam setiap 
organisasi. Oleh karena itu berhasil tidaknya suatu organisasi disebabkan karena perilaku pemimpin yang tidak efektif.

Dalam konteks pemimpin yang mengarahkan Walikota Tangerang Selatan telah melakukan pengarahan yang efektif kepada Dinas Kesehatan dengan memberikan dukungan, berupa motivasi dengan ikut terjun langsung meninjau kondisi terkini di lapangan. Hal tersebut dilakukan sebagai upaya kontrol terhadap Satuan Kerja Perangkat Daerah (SKPD) yaitu Dinas Kesehatan Kota Tangerang Selatan agar selaras dan beriringan guna mensukseskan program prioritas pemerintah daerah. Hasilnya terdapat tren positif sebagai dampak keseriusan pemerintah dalam rangka memenuhi kebutuhan perempuan dan anak. Salah satu bukti nyata yaitu dengan berkurangnya kasus penderita gizi buruk di Kota Tangerang Selatan secara masif.

\section{Dukungan Pemimpin (supportive leader) Sebagai Penentu Keberhasilan}

Berkaitan dengan pemimpin yang mendukung, Kaloh (2009) \& Pasolong (2013) mendefinisikan sebagai pemimpin yang memiliki kesediaan untuk menjelaskan sendiri, bersahabat, mudah didekati, dan mempunyai perhatian yang tinggi terhadap bawahannya. Hal tersebut menegaskan bahwa seorang pemimpin merupakan wadah bagi organisasi yang idealnya memiliki kepekaan dan daya tanggap terhadap segala kebutuhan organisasi. Di samping itu kepedulian kepala daerah sejatinya berorientasi terhadap peningkatan kualitas kehidupan masyarakat. Hal tersebut akan terimplementasikan dengan baik ketika diiringi dengan tindakan responsif yang terartikulasi nyata dan dapat dirasakan masyarakatnya.

Berkaitan dengan konteks kepemimpinan perempuan dalam pemerintahan dalam memenuhi kebutuhan perempuan dan anak, dalam penyelenggaraan pemerintahan oleh Walikota Kota Tangerang Selatan, Airin Rachmy Diani memilki karakteristik pemimpin yang mendukung dengan menunjukan kepeduliannya terhadap jajarannya atau satuan kerja perangkat daerah (SKPD) untuk berkembang dan mencapai tujuan organisasi. Sementara itu Wolfman (1974) dan Sanchez-Hucles \& Davis (2010) menyatakan bahwa keutamaan wanita adalah kemampuan untuk memelihara hubungan. Wanita tertarik untuk membantu orang lain berkembang dan mengungkapkan diri serta menolong mereka memperoleh kepuasan. Sifat memelihara berasal dari peran biologis wanita. Wanita memiliki kemampuan alami untuk mencipta, memilihara, dan mendorong pertumbuhan itu dilakukan demi dan bersama orang lain.

Umumnya salah satu strategi yang dilakukan sebagai langkah akselerasi pembangunan daerah dilakukan melalui pembuatan peraturan daerah (PERDA), dalam upaya memenuhi kebutuhan daerah masing-masing. Dalam konteks Kota Tangerang Selatan sebagai upaya dalam memenuhi kebutuhan perempuan dan anak berdasarkan hasil penelitian, bahwasanya telah terdapat dukungan terhadap pencapaian tujuan organisasi yang datangnya dari Walikota. Seperti adanya Peraturan Walikota Tangerang Selatan Nomor 1 Tahun 2018 tentang Penyelenggaraan Kota Layak Anak (KLA) yang diimplementasikan sebagai langkah nyata mendorong tercapainya tujuan pencapaian Kota Layak Anak (KLA).

Guna mewujudkan Kota Layak Anak (KLA) diperlukan adanya dukungan berbagai pihak lintas sektor dan multi aktor. Hal tersebut dilandasi karena banyaknya indikator yang harus dipenuhi dalam rangka perwujudan menjadi Kota Layak Anak (KLA). Sebagai contoh ketika pemerintah Tangerang Selatan membangun taman atau ruang terbuka hijau dalam memenuhi salah satu syarat kota layak anak, tidak berhenti semata-mata hanya terbatas pada urusan Dinas Kebersihan Pertamanan dan Pemakaman (DKPP). Lebih dari itu memerlukan adanya dukungan SKPD lain seperti Satuan Polisi Pamong Praja (Satpol PP) dalam memastikan tercapainya tujuan. Dalam hal ini untuk memastikan berfungsinya ruang terbuka hijau atau taman dengan semestinya maka dijaga oleh Satuan Polisi Pamong Praja (Satpol PP) yang bergiliran atau bekerja selama 24 jam sehingga dapat dipastikan ruang terbuka untuk bermain anak atau ruang terbuka ramah anak tidak disalahgunakan pada malam hari.

Kondisi di atas tidak lepas dari dukungan kepala daerah sebagai motor penggerak, yang idealnya memiliki sifat cepat dan peduli terhadap kondisi permasalahan di lapangan, di samping membuka diri terhadap segala hal terkait pelaksanaan penyelenggaraan pemerintahan. Terbangunnya kedekatan antara pemimpin dengan jajaran secara langsung atau tidak akan berimplikasi terhadap peningkatan semangat dan motivasi tersendiri. Realisasi supportive leader 
terkonfirmasi dengan pemenuhan kebutuhan perempuan dan anak yang dilakukan oleh Dinas Pemberdayaan Masyarakat Pemberdayaan Perempuan Perlindungan Anak dan Keluarga Berencana (DPMP3AKB). Sejatinya upaya perhatian pemimpin terhadap jajaran, maupun program kerja dari DPMP3AKB akan mendukung terhadap pencapaian Kota Layak Anak (KLA). Tidak dipungkiri pada tahun 2018, jumlah penduduk Kota Tangerang Selatan sebanyak 1.696.308 jiwa. Menelisik data terkait demografi penduduk Kota Tangerang Selatan bahwa jumlah penduduk terbesar di Kota Tangerang Selatan pada tahun 2018 yaitu pada kisaran umur 30 - 34 tahun dengan jumlah 159.648 jiwa. Sedangkan jumlah penduduk anak dengan kelompok umur 0 - 19 tahun yang ada di Kota Tangerang Selatan berjumlah sebanyak 546.227 jiwa. Angka itu menunjukkan bahwa 32,20\% penduduk tahun 2018 adalah kelompok usai anak (Dinas Kependudukan dan Catatan Sipil Kota Tangerang Selatan, 2019).

Sebagai realisasi dukungan terhadap perempuan dan anak, program prioritas Kota Tangerang Selatan salah satunya berupaya memenuhi hak anak, yang aplikasinya dibentuk Forum Anak oleh pemerintah daerah atas inisiasi Walikota Tangerang Selatan. Hal itu guna memenuhi kebutuhan anak dalam setiap pelaksanaan program pembangunan di Kota Tangerang Selatan. Forum Anak beranggotakan kategori anak remaja di bawah 18 tahun, keberadaan forum anak merupakan sarana pelapor dan pelopor bagi penemuhan hak dan perlindungan anak di Kota Tangerang Selatan. Ihwal forum anak sendiri bertujuan untuk menjadikan kota Tangerang Selatan sebagai Kota Layak Anak (KLA), dengan memenuhi 31 hak anak yang menjadi bagian dari hak asasi manusia (HAM) yang wajib dijamin, dilindungi, dan dipenuhi orang tua, keluarga, masyarakat, pemerintah, dan negara. Dari 31 hak anak terdapat hak utama berupa hak untuk hidup, perlindungan, tumbuh kembang dan partisipasi. Sesuai dengan pernyataan informan di atas bahwa dalam memenuhi 31 hak anak pemerintah daerah melakukan pembenahan fasilitas secara berkala.

Salah satu aspek dalam pencapaian Kota Layak Anak (KLA) adalah kesehatan dasar dan kesejahteraan. Di Kota Tangerang Selatan sendiri kesehatan merupakan fokus perhatian dan merupakan salah satu program prioritas Walikota Tangerang Selatan, dan pada tataran kondisi di lapangan pemerintah bersama SKPD secara maksimal memperbaiki permasalahan gizi buruk di Kota Tangerang Selatan. Salah satu kegiatan sebagai dukungan dalam mewujudkan Kota Layak Anak (KLA) yaitu dengan cara penguatan dan pembinaan kader kesehatan yang sebanyak 6000 kader itu terkait dengan pencegahan stunting. Permasalahan stunting merupakan salah satu perhatian dari Walikota Tangerang Selatan. Bentuk lain dari perhatian Walikota Tangerang Selatan yaitu ikut bersama-sama dengan perangkat daerah mulai dari SKPD, Kecamatan, sampai dengan Kelurahan berkumpul bersama dalam forum rapat koordinasi khusus membahas mengenai penurunan dan pencegahan stunting.

Menslisik lebih dalam dukungan Walikota Tangerang Selatan mengarah juga terhadap kesehatan dalam mendukung terselenggaranya pendidikan dengan optimal. Hal tersebut terartikulasi dari berbagai program kesehatan sekolah. Seperti program tablet tambah darah untuk remaja. Dalam konteks tersebut peneliti melihat besarnya kepekaan Walikota Tangerang Selatan dalam pemimpin dan melayani masyarakatnya. Tidak dipungkiri berbagai "riset kepemimpinan" pada birokrasi publik, menunjukan masih lemahnya kepemimpinan dalam berbagai level atau tingkatan. Artinya masih terdapat tingkat penguasaan kepemimpinan yang masih rendah.

Kapasitas dan kesadaran pemimpin yang memiliki kewajiban untuk melayani sangat terbatas bahkan tidak sedikit mereka yang minta untuk dilayani. Kewenangan formal menjadi senjata ampuh dalam menggerakan bawahan. Akibatnya bawahan bekerja bukan atas kesadaran sendiri, tetapi karena tingginya torsi tekanan atasan. Oleh karena itu hubungan antara atasan dan bawahan tidak lagi terjalin dengan harmonis. Padahal keduanya merupakan satu kesatuan tim kerja yang berjalan bersama dalam mensukseskan visi dan misi pemerintah daerah.

Berdasarkan hal di atas berbanding terbalik dengan keadaan di Kota Tangerang Selatan, di mana pemimpin yang memiliki kewenangan formal memberi kebebasan untuk mencapai sasaran organisasi dengan mengembangkan motivasi anggota organisasi. Perilaku Walikota Tangerang Selatan tersebut selaras dengan yang digambarkan oleh Ralph (1974) dalam teori humanstik (humanintic theory) bahwa fungsi kepemimpinan yaitu dengan membuat organisasi 
sedemikian rupa sehingga memberikan kelonggaran pada individu guna mewujudkan motivasi yang potensialnya untuk memenuhi kebutuhan-kebutuhannya dan pada saat yang bersamaan memberikan sumbangan bagi pencapaian tujuan organisasi.

Konteks kepemimpinan perempuan dalam hal ini Walikota Tangerang Selatan berdasarkan analisa peneliti sudah berjalan sesuai dengan koridor visi dan misi. Artinya terdapat kepedulian dengan semata-mata tidak digerakan oleh aturan formal yang kaku, dan senantiasa dapat mengendalikan kewenangan formal yang dimilikinya. Ihwal tersebut menjadi mutlak terpenuhi dalam mewujudkan good governance diperlukan sosok pemimpin yang bersikap terbuka, memiliki komitmen yang tinggi terhadap kinerja pelayanan dan akuntabel dalam semua kebijakan, tindakan maupun langkah-langkahnya. Hal tersebut sesuai dengan pernyataan Eagly (1990) bahwa seorang wanita memiliki sifat demokratis dan rasa kepedulian yang tinggi sehingga sosok wanitapun berkompeten untuk menjadi pemimpin dalam sebuah organisasi

Table 1. Skenaro Kepemimpinan Perempuan di Kota Tangerang Selatan Periode 2011-2021

\begin{tabular}{|c|c|c|}
\hline No. & Program Prioritas & Deskripsi \\
\hline 1 & $\begin{array}{l}\text { Manjemen efektif Satuan Kerja Perangkat } \\
\text { Daerah (SKPD) }\end{array}$ & $\begin{array}{l}\text { Untuk Menciptakan kerja organisasi } \\
\text { (Pemerintahan Kota Tangerang Selatan) } \\
\text { yang terukur dan terkontrol. }\end{array}$ \\
\hline 2 & Ketepatan Regulasi Daerah & $\begin{array}{l}\text { Mengefektifkan implementasi Perda } \\
\text { Nomor } 1 \text { Tahun } 2018 \text { mengenai } \\
\text { Penyelenggaraan Kota Layak Anak (KLA). }\end{array}$ \\
\hline 3 & $\begin{array}{l}\text { Membentuk Satgas (Satuan Tugas) } \\
\text { Perlindungan Anak dan Perempuan } \\
\text { tingkat Rukun Warga (RW) }\end{array}$ & $\begin{array}{l}\text { Upaya pertama dalam rangka } \\
\text { meminimalisir dan melindungi sekaligus } \\
\text { membantu dalam pencegahan kekerasan } \\
\text { terhadap perempuan dan anak. }\end{array}$ \\
\hline 4 & Imlementasi Kolaborasi Program & $\begin{array}{l}\text { Implementasi hukum, kebijakan, program } \\
\text { dan kegiatan pemenuhan hak anak, dengan } \\
\text { melibatkan dunia usaha dalam pemenuhan } \\
\text { hak anak }\end{array}$ \\
\hline
\end{tabular}

Sumber: Olahan Peneliti dari berbagai sumber, 2021

Berdasarkan analisa peneliti bahwa Walikota Tangerang Selatan memiliki totalitas berwujud komitmen dan dukungan secara langsung yang menimbulkan pengaruh motivasi yang kuat terhadap SKPD bahkan masyarakat untuk sama-sama memperbaiki kondisi permasalahan di masyarakat terkait stunting dan gizi buruk sebagai upaya memenuhi kebutuhan perempuan dan anak. Aktivitas turun langsung kepermukaan ditujukan guna memastikan hasil kerja yang sesuai dengan ketentuan. Ihwal tersebut selaras dengan pernyataan Pasolong (2013) bahwa kepemimpinan idealnya dapat mempengaruhi dan memberikan motivasi kepada bawahan, yang berdampak kepada meningkatnya kinerja pegawai yang dipimpinnya. Karena pimpinan dalam struktur formal terlebih birokrasi pasti memiliki bawahan, yang sebab kedudukannya memiliki kekuasaan formal (autority) dan tanggung jawab (akuntabilitas).

Kepedulian Pemerintah Kota Tangerang Selatan terhadap perempuan dan anak menjadikan pada tahun 2018 Kota Tangerang Selatan menyandang predikat Kota Layak Anak (KLA). Secara definisi menurut Perda Nomor 1 Tahun 2018 mengenai Penyelenggaraan Kota Layak Anak adalah kota yang mempunyai sistem pembangunan berbasis hak anak melalui pengintegrasian komitmen dan sumber daya pemerintah, masyarakat, dan dunia usaha yang terencana secara menyeluruh dan berkelanjutan dalam kebijakan program dan kegiatan untuk menjamin terpenuhinya hal anak. Kota Tangerang Selatan secara berkesinambungan dan komprehensif memiliki sistem terintegrasi dalam membangun iklim yang ramah anak, salah satunya mengurangi secara masif tindak kekerasan terhadap anak. Data yang dirilis oleh Dinas Pemberdayaan Masyarakat Pemberdayaan Perempuan Perlindungan Anak dan Keluarga Berencana (DPMP3AKB) Kota Tangerang Selatan tahun 2015, di Kota Tangerang Selatan terdapat enam puluh empat (64) kasus kekerasan terhadap perempuan dan anak. 
Walikota Tangerang Selatan berhasil menurunkan angka kekerasan tersebut yang pada tahun 2015 berjumlah enam puluh empat (64) kasus dan pada tahun 2016 berkurang menjadi lima puluh empat (54) kasus kekerasan terhadap perempuan dan anak. Diketahui bersama dalam mengentaskan permasalahan sosial diperlukan peran serta berbagai pihak, terutama yang datangnya dari keseriusan pemerintah. Dengan adanya kerja sama pemerintah dengan masyarakat secara efektif dapat meningkatkan kemungkinan keberhasilan sebuah pencapaian program sosial. Artinya pemerintah tidak bekerja sendiri, bahkan di era saat ini dalam mengentaskan masalah sosial sangat perlu peran serta dunia usaha. Di Kota Tangerang Selatan sendiri karena perhatian dan fokus pemerintah daerah saat ini telah dibentuk Satuan Tugas Perlindungan Perempuan dan Anak pada setiap RW sebagai wahana kontrol dan tindak pencegahan dini terhadap kekerasan pada perempuan dan anak.

Terobosan dengan membentuk Satgas (Satuan Tugas) Perlindungan Anak dan Perempuan tingkat Rukun Warga (RW) merupakan upaya pertama dalam rangka meminimalisir dan melindungi sekaligus membantu dalam pencegahan kekerasan terhadap perempuan dan anak. Pada implementasinya memberdayakan peran serta masyarakat setempat sebagai garda terdepan dalam memperbaiki kondisi permasalahan di lapangan. Terhitung pada tahun 2017 Satgas Perlindungan Anak dan Perempuan berjumlah 108 orang, dengan jumlah anggota keseluruhan sebanyak 540 orang.

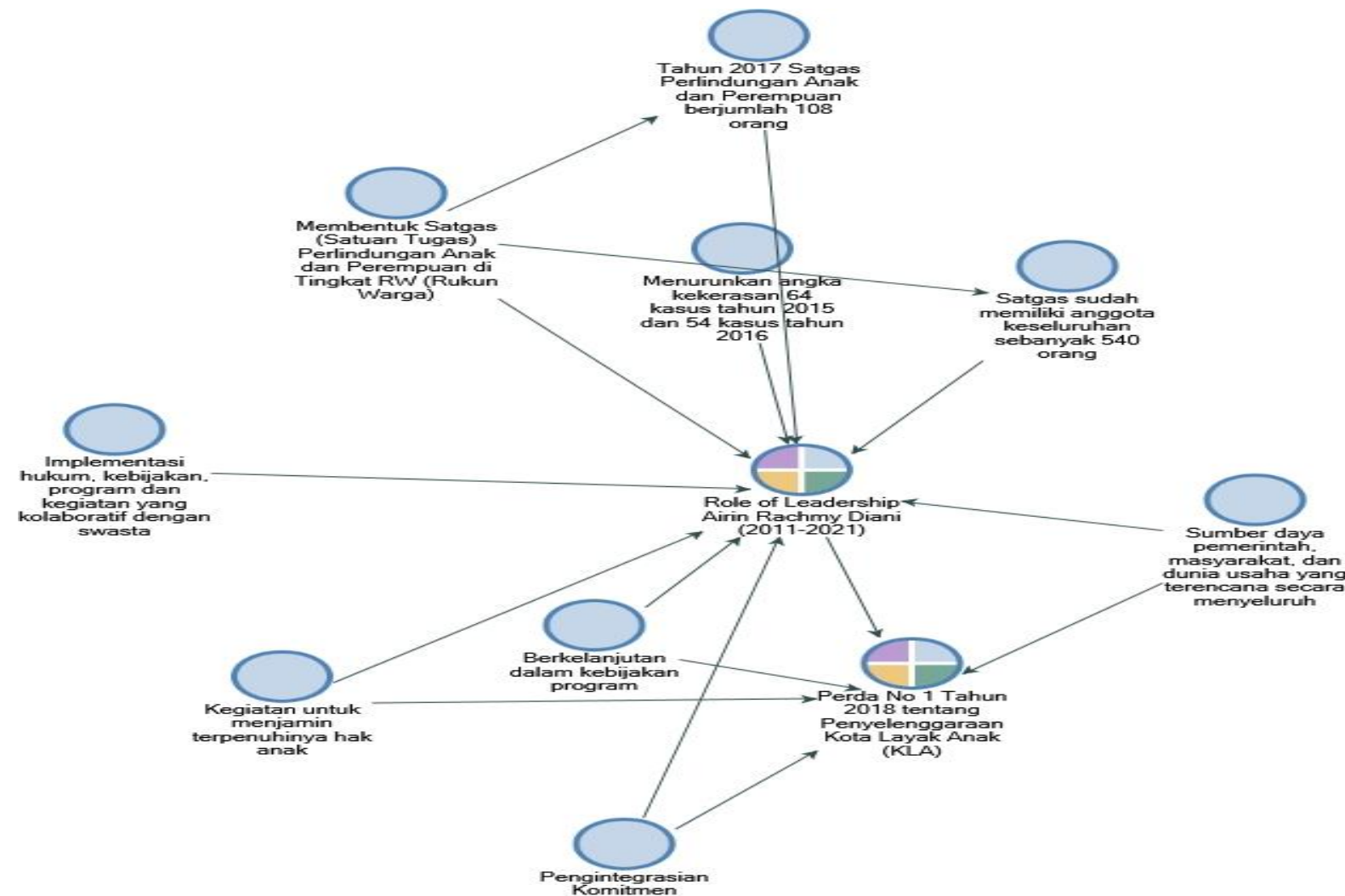

Gambar 3. Eksporasi Kepemimpinan Airin Rahmi Diani sebagai Women's Leadership di walikota Kota Tangerang

Sumber: Olahan Peneliti dengan Nvivo 12 Pro, 2021

Pada gambar 3 di atas dapat di katakan program kebijakan tersebut sebagai dasar tren perbaikan dalam mengakomodir perempuan dan anak di Kota Tangerang Selatan menjelaskan besarnya komposisi pemimpin dalam pemerintahan yang secara langsung bertanggung jawab dalam upaya pemenuhan hak anak. Di samping adanya penguatan kelembagaan serta kapasitas aparat perangkat daerah dalam rangka implementasi hukum, kebijakan, program dan kegiatan pemenuhan hak anak, dengan melibatkan dunia usaha dalam pemenuhan hak anak dan 
perempuan. Upaya yang dilakukan oleh Airin Rachmy Diani Periode walikota Kota Tangerang Selatan sejak 2011-2021.

\section{KESIMPULAN}

Walikota Tangerang Selatan sebagai pemimpin yang memiliki kesediaan untuk menjelaskan sendiri, bersahabat, mudah didekati, dan mempunyai perhatian yang tinggi terhadap bawahannya. walikota tangerang selatan telah melakukan pengarahan yang efektif kepada dinas kesehatan dengan memberikan dukungan, berupa motivasi dengan ikut terjun langsung meninjau kondisi terkini di lapangan. hal tersebut dilakukan sebagai upaya kontrol terhadap satuan kerja perangkat daerah (SKPD) yaitu dinas kesehatan kota Tangerang Selatan agar selaras dan beriringan guna mensukseskan program prioritas pemerintah daerah. berkaitan dengan pemimpin yang mendukung walikota tangerang memiliki totalitas berwujud komitmen dan dukungan secara langsung yang menimbulkan pengaruh motivasi yang kuat terhadap skpd bahkan masyarakat untuk sama-sama memperbaiki kondisi permasalahan di masyarakat terkait stunting dan gizi buruk sebagai upaya memenuhi kebutuhan perempuan dan anak. lebih dari itu walikota Tangerang Selatan berinovasi dengan membentuk satgas (Satuan Tugas) perlindungan anak dan perempuan tingkat rukun warga (RW) merupakan upaya pertama dalam rangka meminimalisir dan melindungi sekaligus membantu dalam pencegahan kekerasan terhadap perempuan dan anakmemaparkan kesimpulan, implikasi, batasan dan saran penelitian secara berurutan. implikasi adalah nasehat praktis dari hasil penelitian. batasan penelitian mencakup hal-hal yang dapat dilakukan peneliti dalam melakukan penelitiannya. sedangkan saran merupakan saran untuk penelitian selanjutnya berdasarkan keterbatasan yang tidak dapat dilakukan peneliti dalam penelitiannya.

\section{REFERENSI}

Abdillah, A., Deliarnoor, N. A., Yuningsih, N. Y., \& Fatmawati, F. (2020). The Position of Auxiliary Organ in Government System of West Java Provincial Government. Journal of Contemporary Governance and Public Policy, 1(2), 67-81. Doi: https://doi.org/https://doi.org/10.46507/jcgpp.v1i2.11

Adiguna, A. P., Rifaid, R., \& Rusnaedy, Z. (2020). Problematics of Multiparty Systems in Indonesia. Journal of Governance and Local Politics (JGLP), 2(1), 93-105. Doi: https://doi.org/10.47650/jglp.v2i1

Anirwan, A., \& Annas, A. (2020). Upaya Peningkatan Kinerja Layanan Sekretariat DPRD Kabupaten Soppeng. Journal of Governance and Local Politics (JGLP), 2(2), 131-150. Doi: https://doi.org/10.47650/jglp.v2i2

Bass, B. M. \& Avolio, B. J. (1994). Improving Organizational Effectiveness through Transformational Leadership. Thousand Oaks: Sage Publications.

Bass, B. M. (1985). Leadership and Performance Beyond Expectations. New York: The Free Press.

Creswell, John W. (2015). Research Design Pendekatan Kualitatif, Kuantitatif, dan Mixed. Yogyakarta: Pustaka Pelajar.

Drucker, P.F. (1993). Post-Capitalist Socienty. New York: Harper Business.

Eagly, Alice H., \& Johnson, B. T. (1990). Gender dan Leadership Style: A Meta Analisys. CHIP Documents. Paper 11.

Fakih, M. (1996). Analisis Gender dan Transformasi Sosial. Yogyakarta: Pustaka Pelajar

Hersey, Paul dan Kenneth. H. Blanchard., (2003). Manajemen Perilaku Organisasi: Pendayungan Sumber Daya Manusia, Terjemahan Agus Dharma. Jakarta:Erlangga.

House, R. (1971). A Path Goal Theory of Leader Effectiveness. Administrative Science Quarterly, 16(3), 321- 339. doi:10.2307/2391905

Kaloh, J. (2009). Kepemimpinan Kepala Daerah; Pola Kegiatan, Kekuasaan, dan Perilaku Kepala Daerah dalam Pelaksanaan Otonomi Daerah. Jakarta: Sinar Grafika.

Kanter, R.M. (1977). Restoring People to The Hearth of the Organization of the Future, in the Organization Future. San Francisco: Jossey Bass Publisher 
Lewin K., Lippit R., \& White, R. K. (1939). Patterns of Aggressive Behavior in Experimentally Created "Social Climates". The Journal of Social Psychology, 10(2), 269-299. doi:10.1080/00224545.1939.9713366.

Luhur, A., \& Abdillah, A. (2020). Dekolonisasi dan Indegenisasi Ilmu Pemerintahan. Governabilitas (Jurnal Ilmu Pemerintahan Semesta), 1(2), 164-186. Doi: https://doi.org/10.47431/governabilitas.v1i2.86

Malik, I., Abdillah, A., Rusnaedy, Z., \& Khaerah, N. (2021, May). Coastal Women's Resilience Strategy against Climate Change Vulnerability in Makassar, Indonesia. In E3S Web of Conferences (Vol. 277, p. 01003). Doi: https://doi.org/10.1051/e3sconf/202127701003

Meleoong, L. J. (2007). Metodelogi Penelitian Kualitatif. Bandung: PT. Remaja Rosdakarya.

Miller,G.A. (1974). Prentice Psychology and Communication in Social Conflict. Englewood Clifffs -Hall, Inc

Pamudji. (1992). Kepemimpinan Pemerintahan di Indonesia. Jakarta: Bumi Aksara.

Parker, P. S. (1996). Gender, culture, and leadership: Toward a culturally distinct model of African-American women executives' leadership strategies. The Leadership Quarterly, 7(2), 189-214. Doi: https://doi.org/10.1016/S1048-9843(96)90040-5

Pasolong, H. (2013). Kepemimpinan Birokrasi. Jakarta: Alfabeta.

Prastio, L. O. (2019). Strategi Program Pemberdayaan Usaha Garam Rakyat Di Desa Muara Baru Kecamatan Cilamaya Wetan Kabupaten Karawang. The Indonesian. Journal of Politics and Policy, 1(1), 62-73. Doi: https://doi.org/10.35706/ijpp.v1i1.1647

Prastio, L. O., Suwaryo, U., \& Yuningsih, N. Y. (2019). Pengaruh Kepercayaan dan Komitmen Antar Aktor Terhadap Proses Kolaborasi Pada Program Pemagangan Nasional di Kabupaten Karawang. Jurnal Politikom Indonesiana, 4(2), 200-223. Doi: https://doi.org/10.35706/jpi.v4i2.3243

Prianto, A. L., Malik, I., Rusneady, Z., Khaerah, N., Abdillah, A., Lestari, D., Angraini, R., (2021). Demokrasi Lokal dan Pemilihan Kepala Daerah Pasangan Calon Tunggal. Makassar: Subaltern Inti Media

Ralph. S. (1974). A Handbookbof Leadership. The Free Press, New York: Coller Machmillan Publishers, London.

Riskasari, R. (2021). Pengembangan Objek Wisata Alam Uwae Pellae dalam Meningkatkan Pendapatan Retribusi Wisata di Dinas Pariwisata dan Kebudayaan Kabupaten Sinjai. Journal of Governance and Local Politics (JGLP), 3(1), 75-86. Doi: https://doi.org/10.47650/iglp.v3i1

Sanchez-Hucles, J. V., \& Davis, D. D. (2010). Women and women of color in leadership: Complexity, identity, and intersectionality. American Psychologist, 65(3), 171-181. Doi: https://doi.org/10.1037/a0017459

Suradinata. (2007). Gaya Kepemimpinan. CV Pustaka Pelajar. Yogykarta.

Sutikno, Raja Bambang. (2007). The Power OF Emphaty in Leadership. Jakarta, Gramedia.

Tati, T., Rusdiana, D., Doni, D., \& Nugraha, S. (2021). Identifikasi Pelanggaran AMDAL Mega Proyek Wisata Pulau Komodo Nusa Tenggara Timur. Jurnal Identitas, 1(1), 42-52.

Wirawan. (2014). Kepemimpinan: Teori,Psikologi,Perilaku Organisasi, Aplikasi Penelitian. Depok: PT Rajagrafindo Persada.

Wolfman, B. R. (1989). Peran Kaum Wanita. (Soetomo, Trans.) Yogyakarta: Kanisius.

Woolf, N. H., \& Silver, C. (2017). Qualitative analysis using NVivo: The five-level QDA® method. Routledge.

Yukl, G. (2010). Kepemimpinan dalam Organisasi. Edisi kelima. Jakarta: Indeks.

Yusuf, M., Jariah, A., \& Sadar, S. (2020). Penerapan NPS dalam Pelayanan Penerbitan SKPD Kendaraan Bermotor Berbasis Online pada SAMSAT Kalimantan Tengah. Journal of Governance and Local Politics (JGLP), 2(2), 191-200. Doi: https://doi.org/10.47650/jglp.v2i2

\section{Dokumen:}

Perda Nomor 1 Tahun 2018 mengenai Penyelenggaraan Kota Layak Anak.

Laporan Dinas Kesehatan Kota Tangerang Selatan, 2019. 
Dinas Kependudukan dan Catatan Sipil Kota Tangerang Selatan, 2019.

\section{Website:}

Eko. (2019). "Gizi Buruk dan Stunting di Banten Meningkat, Dipicu Minimnya Pengetahuan Orang Tua". https://www.tribunnews.com/regional/2019/05/15/gizi-buruk-danstunting-di-banten-meningkat-dipicu-minimnya-pengetahuan-orangtua. Diakses Pada 16 Desember 2019. Pukul 20:33 WIB.

Guritno, Tatang. (2019). "Pemkot Tangsel Sebut Anak-anak Mendominasi Korban Kekerasan Tahun 2018" https://megapolitan.kompas.com/read/2019/02/11/17143151/pemkottangsel-sebut-anak-anak-mendominasi-korban-kekerasan-tahun-2018. Diakses pada 15 Januari 2020. Pukul 15:32 WIB.

Ridho, Rasyid. (2017). "Kasus Kekerasan terhadap Perempuan dan Anak di Banten Tinggi". Pusat Pelayanan Terpadu Pemberdayaan Perempuan dan Anak (P2TP2A, 2017).

Sahurina, Maya. (2020). "Menteri Yohana Sebut Perempuan di Banten Kurang Perhatian". https://tangerangnews.com/banten/read/25437/Menteri-Yohana-Sebut-Perempuandi-Banten-Kurang-Perhatian. Diakses pada Diakses pada 15 Janari 2020. Pukul 16:12 WIB. 